Frederick Lauritzen (Venice)

\title{
The LAyers of Composition of The SyNodikon of Alexius Studites
}

\footnotetext{
$\mathrm{T}$
} he Synodikon of Orthodoxy has many layers of composition. Scholars, such as Gouillard ${ }^{1}$, have divided the Synodikon into at least three phases (Macedonian, Comnenian, and Palaeologan). The new edition of the $11^{\text {th }}$ century Synodikon ${ }^{2}$ yields information about the layers of composition between the $9^{\text {th }}$ and $11^{\text {th }}$ centuries. This article explores the numerous layers which may be detected in the earliest Synodikon (Synodikon of Alexius Studites).

In 1980 Cyril Mango claimed ${ }^{3}$ that the text of the Synodikon had not changed between 843 and 1082 when the anathemas directed against John Italus were add$\mathrm{ed}^{4}$. He based his claim on the research of Gouillard who had subdivided the text into Synodikon $M, C$ and $P$. Within Synodikon $M$ he also added the anathemas of Italus which were, however, issued under Alexius I Comnenus (1081-1118) and not under the Macedonian dynasty $(868-1056)^{5}$. The anathemas appear in three manuscripts which do not reflect the earlier version of the Synodikon. Moreover, he did not indicate that the six earliest manuscripts contain a rather stable text which may be dated to the patriarchate of Alexius Studites ${ }^{6}$. The recent critical edition based on a new reading of the manuscripts has the advantage that it reflects a text present in the manuscripts. The difficulty of employing Gouillard's text is that it is fundamentally a composite edition of numerous versions including variants

\footnotetext{
${ }^{1}$ J. Gouillard, Le Synodikon de L'orthodoxie: Édition et Commentaire, TM 2, 1967, p. 1-316.

${ }^{2}$ Synodikon of Alexios Studites (1025-1043), ed. F. Lauritzen, [in:] The Great Councils of the Orthodox Churches. From Constantinople 861 to Moscow 2000, ed. A. Melloni, vol. I, Turnhout 2016 [= CC.COGD 4.1] (cetera: Synodikon of Alexios Studites), p. 375-394.

${ }^{3}$ C. Mango, Byzantium: the Empire of New Rome. History of Civilisation, London 1980, p. 102.

${ }^{4}$ Synod of 1082, ed. F. Lauritzen, [in:] The Great Councils..., p. 71-84.

${ }^{5}$ L. Clucas, The Trial of John Italos and the Crisis of Intellectual Values in Byzantium in the Eleventh Century, Munich 1982.

${ }^{6}$ F. LAuritzen, Against the Enemies of Tradition: Alexios Studites and the Synodikon of Orthodoxy, [in:] Orthodoxy and Heresy in Byzantium. The Definition and the Notion of Orthodoxy and Some Other Studies on the Heresies and the Non-Christian Religions. Proceedings of the XX Annual Conference of Saint Tikhon University, ed. A. Rigo, P. Ermilov, Rome 2010, p. 41-48.
} 
originating from local churches. Therefore, the new text reflects the Synodikon as it was in the period 1034-1043. This Synodikon of Alexius Studites has a stable text with few variants from one manuscript to another, even if one may detect a number of alterations since the first text of $843 / 844$. It is difficult to know when they were added but one can here isolate them. Once isolated, they indicate a clear date after which they were added. Since the Synodikon of Alexius Studites is dated to a period between 1034-1043 that is the date before which they were added.

The preamble of the Synodikon describes an event which occurred one year after the end of the iconoclast controversy ${ }^{7}$. Indeed, the Synodikon is fundamentally the commemoration of the end of iconoclasm. Therefore, the basic framework is from 844 . The structure of the text is constituted of six sections: 1. introduction; 2. blessings; 3 . saints; 4 . anathemas; 5 . emperors; 6 . patriarchs.

The first and second sections appear to have biblical quotations and theological references to the questions more or less related to icons and therefore are difficult to date. It is possible that this part of the text was not altered after 844 .

Section three has a preamble which may be original (3.1-15) and then a section dedicated to the patriarchs considered blessed in 844 (3.16-18). It also adds a paragraph on subsequent patriarchs: Ignatius (847-857; 867-877), Photius (858867; 877-886), Stephen (886-893), Anthony (893-901) and Nicholas (912-925) (3.19-20 and 3.21-23). It is clear that the list of patriarchs in the current form dates to a time after 925 (death of Nicholas I). Gouillard indeed had considered a second redaction of the Synodikon dating to the first half of the $10^{\text {th }}$ century. Moreover, the anathema 'against all enemies of tradition' is inserted after this list of patriarchs (3.24-26) and also appears in the Tomos of Union of $920^{8}$. Therefore, section three is divided into two sections: $3.1-18$, dated to mid $9^{\text {th }}$ century and 3.19-26, added after 925. Gouillard does not appear interested in the list of saints mentioned at $3.27-42^{9}$ and does not devote specific notes to these saints:

3.27: Euthymius, Theophilus, Aemilianus - Euthymius, bishop of Sardis ( $† 840)$ under Theophilus; Theophilus, bishop of Ephesus; Aemilianus, bishop of Cyzicus $(† 820)$ under Leo V;

3.29: Theophylact, Peter, Michael, Joseph metropolitans - Theophylact, bishop of Nicomedia ( $\dagger 846$ ); Peter of Atroa ( $\dagger 837$, worked with Ioannicius); Michael, bishop of Synada ( $\dagger 821)$; Joseph, bishop of Thessalonica ( $\dagger 830$, brother of Theodore Studites);

3.31: John, Nicholas, George Confessors archbishops - John Confessor, abbot of monastery of Katharon ( $\uparrow 839)$; Nicholas Confessor, abbot of Studios ( $† 868)$; George, bishop of Mytilene ( $† 821)$;

\footnotetext{
${ }^{7}$ Synodikon of Alexios Studites, 1. 1-3; p. 377.

${ }^{8}$ On this anathema vide: F. Lauritzen, Against the Enemies of Tradition..., p. 41-48.

${ }^{9}$ Even though the text is different, the reference is: J. Gouillard, Le Synodikon..., 1. 120-133.
} 
3.34: Theodore Studite $(† 826)$;

3.35: Isaac Wonderworker and Ioannicius - Isaac ( $†$ 396), abbot of Dalmatou; Ioannicius the Great ( $† 846)$;

3.37: Hilarion, archimandrite and abbot of Dalmatou ( $† 845)$;

3.39: Symeon Stylites (of Lesbos, $\uparrow 844$ );

3.40: Stephen the Younger $(\dagger 764)$;

3.41: Germanus, ecumenical patriarch $(† 740)$.

The list of saints reveals that most concerned with the period of the second iconoclasm (814-842). However there are a few names which cannot have been included in the earliest version of the text: Theophylact of Nicomedia $(\dagger 846)$; Nicholas of Studios ( $\dagger$ 868); Ioannicius ( $\uparrow 846$ ); Hilarion, abbot of Dalmatou $(\dagger 845)$; Symeon Stylites of Lesbos $(\dagger 844)$. These must have been added after the original text was composed, probably in a period $845-870$. It is striking that the two last names are to be found only in one manuscript and that they refer to persons who died during the first iconoclasm. The section, otherwise, commemorates saints actively involved in the second iconoclasm (814-842). Moreover, there is an important addition of the role of the Dalmatou ${ }^{10}$ and Studios ${ }^{11}$ monasteries. This insight is further confirmed by an event concerning the Synodikon mentioned as the revolt of Mermentulus in the chronicle of John Scylitzes for the year 1044:

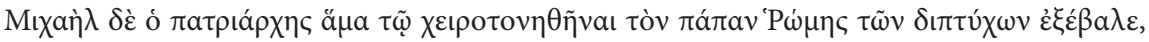

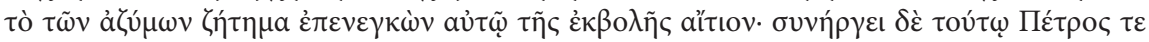

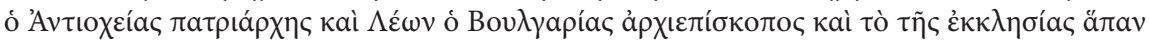

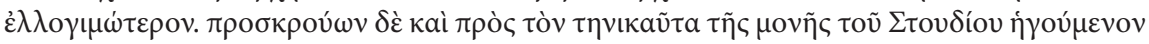

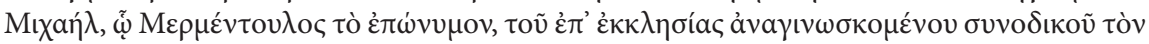

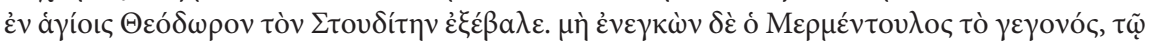

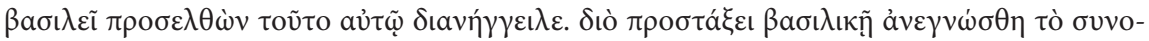

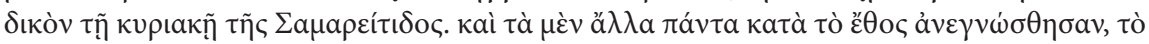

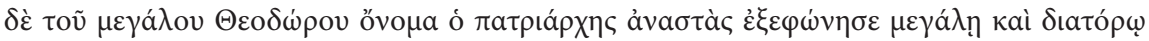

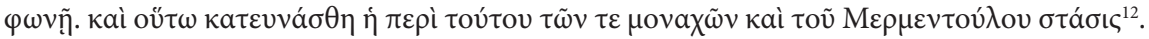

\footnotetext{
${ }^{10}$ A.-M. TAlbot, Dalmatou Monastery, [in:] ODB, p. 579.

${ }^{11}$ O. Delouis, Saint-Jean-Baptiste de Stoudios à Constantinople. La contribution d'un monastère à l'histoire de l'Empire byzantin (v. 454-1204) (in press).

${ }^{12}$ Ioannis Scylitzae Synopsis Historiarum, 9.7.3-13, ed. I. Thurn, Berolini-Novi Eboraci 1973, p. 433-434. As soon as Michael was elected patriarch he removed the pope of Rome from the diptychs, alleging the question of the unleavened bread as the reason for exclusion; Peter, patriarch of Antioch collaborated with him and Leo, metropolitan of Bulgaria, and all the most intellectual section of the church. He attacked also Michael, surnamed Mermentulus, the abbot of that time of the monastery of Studios, and while he [Cerularius] was reading the Synodikon in church he removed the name of Saint Theodore Studites. Mermentulus could not bear this event, went to the emperor and reported the event to him.
} 
This text reveals that Studite influence on the Synodikon was important. Indeed, the patriarch thought he had the authority to remove something he considered an addition. This behaviour may reveal his attitude towards his predecessor who had been a Studios monk (Alexius Studites). However, it does reveal that, according to Cerularius, the text of the Synodikon had been altered to increase the importance of the Studios monastery. To give him the benefit of the doubt, he may have even been reading an ancient manuscript which did not contain the name of Theodore: but this is speculation. What is certain is that in 1043-1044, the most usual text included the name of the Studios monk.

The introduction to section $4(4.1-5)$ and the anathemas (4.6-43) may have been part of the document of 844, since they concern specifically the iconoclast question. Here one finds additional anathemas (4.44-53 and 4.57-64). Gouillard in his apparatus did also identified them as coming from the acts of the council of 869-870 and must have been added after 870 . Between the two sets of anathemas from the council of 869 , one finds also the three anathemas against all heretics, all Jacobites and all Nestorians (4.54-56). These fit remarkably well with the interests of Alexius Studites who had often attacked the Jacobite community. Dagron pointed out that the Syriac community became more prominent within the Byzantine Empire after the year $1025^{13}$. It would seem that the reference to Jacobites could easily be associated with the redaction of the Synodikon of Alexius Studites. The same may be said for the twenty-three anathemas present in the oldest manuscript of the Synodikon (4.70-141). They are directed against a dualist sect. Among the synods of Alexius Studites can be found also references to the Euthymius of Akmonia who wrote in the Peribleptos monastery at the time of Romanus III (1028$1034)^{14}$. While it is true that the account of Cosmas the Priest in Slavonic is earlier, the question here is about a document issued in Constantinople about perceived threats originating from heresies. Before Euthymius of Akmonia or Peribleptos it is not clear how aware Constantinople was of the dualist question in the Balkans and Eastern Anatolia. The fourth section of the Synodikon has an original nucleus of the mid $9^{\text {th }}$ century $(4.1-43 ; 4.65-69)$, a part after $870(4.44-53 ; 4.57-64)$, $11^{\text {th }}$ century section $(4.54-56 ; 4.70-141)$.

The fifth section of the Synodikon has a list of invocations (5.1-4) and prayers for the emperor Michael III and his mother Theodora (5.9-10) which must be original. Next is a list of emperors, ending with Romanus III (1034) and a list of empresses before the empress Zoe ( $† 1050)$ which were modified later on (at the latest in the $11^{\text {th }}$ century) (5.11-16).

Therefore, the Synodikon was read by imperial order on the Sunday of the Samaritan woman. And the rest was read according to custom, and the patriarch stood and cried out the name of the great Theodore with a loud and clear voice. Thus the rebellion of the monks and Mermentulus was put to rest.

${ }^{13}$ G. Dagron, Minorités ethniques et religieuses dans l'Orient byzantin à la fin du Xe siècle et au XI ${ }^{e}$ siècle l'immigration syrienne, TM 6, 1976, p. 177-216.

${ }^{14}$ A. KAZHDAN, Euthymios of Akmonia, [in:] ODB, p. 756. 
The sixth section has a list of patriarchs of Antioch from the year 960 to 1010 (6.1-2). This seems to reflect the situation resulting in the re-conquest of Antioch in 969. It is unknown why the list ends with Elias II (1010). Moreover, the list appears in only one of the manuscripts and may reflect a specific interest of that version. The list is followed by a list of patriarchs of Constantinople such as was available in $844(6.3-4)$ and another more complete and recent list from Ignatius to Eustathius (1025) (6.5-8).

It is clear that there are numerous layers of the Synodikon of Alexius Studites. One may summarize them as follows:

a) possibly original text of $844: 1 ; 2 ; 3.1-18 ; 4.1-43 ; 4.65-69 ; 5.1-3 ; 5.9-10 ; 6.3-4$;

b) modification after $845: 3.27-42$;

c) modification after $870: 4.44-53$; 4.57-64;

d) modifications after 925:3.19-26;

e) modifications between 1010-1043: 4.54-56; 4.70-141; 5; 6.1-2; 6.5-8.

It is therefore a fact one may detect numerous layers in the Synodikon of Alexius Studites. The list above provides a simple post quem, after which date, these modifications must have been added. It shows how a number of passages cannot have been present in the text of 844 . The real question is: why modify the text?

The overall structure of the Synodikon is obviously original. All six sections seem to have texts which could date to 844 . It appears that section 1 and 2 may possibly be original. The modifications after 845 (3.27-42) seem to concern the struggle against iconoclasm specially during the period $814-842$. The reference to theologians / Confessors from the Dalmatou and Studios monastery seems to imply their importance in promoting the Triumph of Orthodoxy after 843. Considering the importance of the monasteries outside Constantinople during iconoclasm, it is clear these two Constantinopolitan monasteries wished to play a role in the restoration of Orthodoxy by promoting their saints who had fought against iconoclasm. For this reason, the additions may be rather soon after 845. The next series of additions concern the anathemas recited at the council of 869 (4.44-53; 4.57-64). These anathemas concern specifically iconoclasts of the first iconoclasm (730-787). Kountoura Galake has pointed out that the persons singled out in some of these anathemas (4.48-53) have surnames. She is exploring the possibility that Constantine $\mathrm{V}$ promoted the use of surnames, but here it reveals a homogeneous group of persons identified in a similar manner ${ }^{15}$. At 4.45 the Isaurian dynasty (717-802) is singled out. The fact a dynasty is singled out, may indicate the presence of a new dynasty. Given that these anathemas appear after 869 it would appear that it is the Macedonian dynasty (867-1056). If that were the case it would probably be

\footnotetext{
${ }^{15}$ E. Kountoura Galake, Iconoclast Officials and the Formation of Surnames during the Reign of Constantine V, REB 62, 2004, p. 247-253, esp. p. 250.
} 
under Basil I (867-886) or Leo VI (886-912). It is striking that the anathemas concern specifically the first period of iconoclasm and this in itself may reveal a later addition. The additions undertaken after the death of Nicholas I Mysticus (925) are taken from the synod of 920 on the fourth marriage of the emperor (tetragamia). The anathemas (3.19-26) are taken from the section of the anathemas of the text of $920^{16}$. The last additions appear to date the time of Alexius Studites specifically. His interest in dualist heresies and attacking both Nestorians and Jacobites is well reflected in the synod decrees of his rule (1025-1043).

To summarize: there are four phases of additions which reflect different mentalities:

1) after 845 - monastic interest in the Dalmatou and Studios monasteries;

2) after 870 - iconoclasts of Isaurian dynasty of first iconoclasm;

3) after 920 - anathemas of Nicholas Mysticus;

4) after 1025 - dualist heresies and Nestorians/Jacobites.

Schematically there are two main periods of modifications: the period 845-925 and the period 1010-1043. Gouillard had indicated a first revision in the early $10^{\text {th }}$ century. However, one cannot compress the first three phases of composition, since they have different aims. The first promotes the action of monasteries of Constantinople, the second is concerned with first iconoclasm and the third integrates the anathemas of the synod of 920 into the Synodikon. For this reason, it would appear that rather than one modification proposed by Gouillard, one should look at four phases after the original composition. While these gradual additions reflect different interests, attitudes and concerns, it also clear that the reedition of a stable text under Alexius Studites indicates that in the second quarter of the $11^{\text {th }}$ century the five different phases (one original and four modifications) reflected a single cohesive spirit. It was for this reason that the Synodikon of Alexius Studites, and not a previous version, is the text from which originate the translations into Georgian ${ }^{17}$, Bulgarian ${ }^{18}$, Serbian ${ }^{19}$ and Russian ${ }^{20}$.

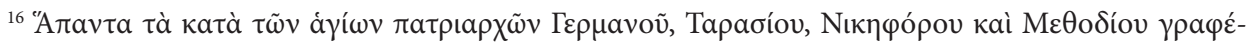

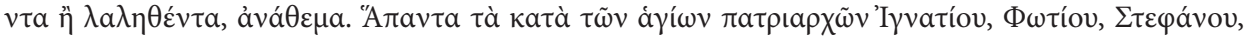

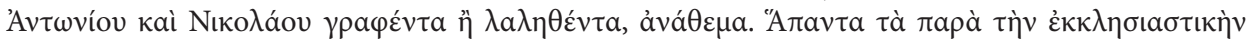

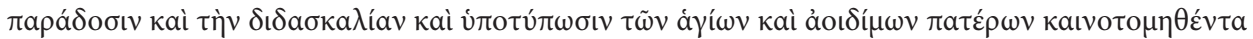

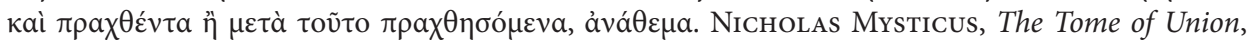
[in:] Nicholas I, Patriarch of Constantinople. Miscellaneous Writings. Greek Text and English Translation, ed. L.G. WesterinK, Washington, D.C. 1981 [= CFHB, 20], p. 70.

${ }^{17}$ Synodicum Georgicum, ed. B. Martin Hisard, [in:] The Great Councils..., p. 397-425.

${ }^{18}$ Synodicum Bulgaricum 1211, ed. A. Totomanova, [in:] The Great Councils..., p. 426-468.

${ }^{19}$ Synodicum Serbicum, ed. T. Subotin-Golubović, [in:] The Great Councils..., p. 469-476.

${ }^{20}$ Synodicum Russicum, ed. K.A. MaKsimovič, [in:] The Great Councils..., p. 477-518.
} 


\section{Bibliography}

\section{Sources}

Ioannis Scylitzae Synopsis Historiarum, ed. I. Thurn, Berolini-Novi Eboraci 1973.

Nicholas Mrsticus, The Tome of Union, [in:] Nicholas I, Patriarch of Constantinople. Miscellaneous Writings. Greek Text and English Translation, ed. L.G. Westerink, Washington, D.C. 1981 [= CFHB 20], p. 56-85.

Synod of 1082, ed. F. Lauritzen, [in:] The Great Councils of the Orthodox Churches. From Constantinople 861 to Moscow 2000, ed. A. Melloni, vol. I, Turnhout 2016 [= CC.COGD 4.1], p. 71-84.

Synodicum Bulgaricum 1211, ed. A. Totomanova, [in:] The Great Councils of the Orthodox Churches. From Constantinople 861 to Moscow 2000, ed. A. Melloni, vol. I, Turnhout 2016 [= CC.COGD 4.1], p. 426-468.

Synodicum Georgicum, ed. B. Martin Hisard, [in:] The Great Councils of the Orthodox Churches. From Constantinople 861 to Moscow 2000, ed. A. Melloni, vol. I, Turnhout 2016 [= CC.COGD 4.1], p. 397-425.

Synodicum Russicum, ed. K.A. Maksimovič, [in:] The Great Councils of the Orthodox Churches. From Constantinople 861 to Moscow 2000, ed. A. Melloni, vol. I, Turnhout 2016 [= CC.COGD 4.1], p. 477-518.

Synodicum Serbicum, ed. T. Subotin-Golubović, [in:] The Great Councils of the Orthodox Churches. From Constantinople 861 to Moscow 2000, ed. A. Melloni, vol. I, Turnhout 2016 [= CC.COGD 4.1], p. 469-476.

Synodikon of Alexios Studites (1025-1043), ed. F. Lauritzen, [in:] The Great Councils of the Orthodox Churches. From Constantinople 861 to Moscow 2000, ed. A. Melloni, vol. I, Turnhout 2016 [= CC.COGD 4.1], p. 375-394.

\section{Secondary Literature}

Clucas L., The Trial of John Italos and the Crisis of Intellectual Values in Byzantium in the Eleventh Century, Munich 1982.

Dagron G., Minorités ethniques et religieuses dans l'Orient byzantin à la fin du Xe siècle et au XI siècle l'immigration syrienne, "Travaux et Mémoires du Centre de recherches d'histoire et civilisation byzantines" 6, 1976, p. 177-216.

Delouis O., Saint-Jean-Baptiste de Stoudios à Constantinople. La contribution d'un monastère à l'histoire de l'Empire byzantin (v. 454-1204) (in press).

Gouillard J., Le Synodikon de L'orthodoxie: Édition et Commentaire, "Travaux et Mémoires du Centre de recherches d'histoire et civilisation byzantines" 2, 1967, p. 1-316.

Kazhdan A., Euthymios of Akmonia, [in:] The Oxford Dictionary of Byzantium, ed. A.P. Kazhdan, New York-Oxford 1991, p. 756.

Lauritzen F., Against the Enemies of Tradition: Alexios Studites and the Synodikon of Orthodoxy, [in:] Orthodoxy and Heresy in Byzantium. The Definition and the Notion of Orthodoxy and Some Other Studies on the Heresies and the Non-Christian Religions. Proceedings of the XX Annual Conference of Saint Tikhon University, ed. A. Rigo, P. Ermilov, Rome 2010, p. 41-48.

Mango C., Byzantium: the Empire of New Rome. History of Civilisation, London 1980. 
Kountoura Galake E., Iconoclast Officials and the Formation of Surnames during the Reign of Constantine V, "Revue des études byzantines" 62, 2004, p. 247-253.

Тацвот A.-M., Dalmatou Monastery, [in:] The Oxford Dictionary of Byzantium, ed. A.P. Kazhdan, New York-Oxford 1991, p. 579.

\begin{abstract}
The Synodikon of Orthodoxy, in its earliest version (Synodikon of Alexius Studites), has at least five different layers of composition. Beside the original one of $843 / 844$, there is one after 845 , another after 870, a fourth after 925 and finally one between 1034-1043. Since each date represents a post quem, they could be grouped together. However, the layers of composition represent different interests and objectives and therefore are difficult to conflate. On the contrary, each stratum reveals that by the $11^{\text {th }}$ century the characteristic of the Synodikon was to unify different objectives and strategies into one text. It is also for this reason that the text continued to expand after Alexius Studites version of 1034-1043.
\end{abstract}

Keywords: Synodikon of Orthodoxy, Alexius Studites, textology

Frederick Lauritzen

Scuola Grande di San Marco, Venezia To contact the author, please write to the editorial board of the journal. 